) Innlegg på inntil $\mathbf{4 0 0}$ ord lastes opp i http://mc.manuscriptcentral.com/tidsskriftet.

Redaksjonen forbeholder seg retten til å foreta redaksjonelle endringer.

Forfattere av vitenskapelige artikler har tilsvarsrett (jf. Vancouver-gruppens regler).

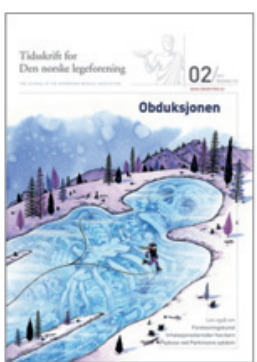

\section{Epler og pærer må ikke sammenliknes}

I Tidsskriftet nr. 2/2012 undres Stine Bjerkestrand i en interessant leder (1) hvorfor Larun \& Malteruds artikkel om treningsbehandling ved kronisk utmattelsessyndrom (ME) (2) fikk så lite oppmerksomhet, mens Fluge og medarbeideres artikkel (3) om rituximabbehandling av pasienter med samme tilstand fikk svært stor medieoppmerksomhet. Hun er i den forbindelse også innom et TV2-intervju med meg i kjølvannet av Fluge og medarbeideres artikkel hvor jeg ber om at det blir gjort en granskning av den behandling pasienter med kronisk utmattelsessyndrom har fått av det norske helsevesenet.

Mine synspunkter på dette har imidlertid ikke noen sammenheng med Fluge og medarbeideres studie. Jeg har flere ganger offentlig tatt til orde for at tilbudet til disse pasientene må bedres. Dette er basert på egne erfaringer da jeg våren 2008 begynte å reise rundt til de sykeste pasientene med kronisk utmattelsessyndrom på Østlandet. Det var et sjokk å se så syke mennesker nærmest stuet vekk i private hjem, ofte holdt i live av de nærmeste pårørende, uten tilsyn fra helsetjenesten. Dette er mennesker som er så syke at helsevesenet ikke klarer å fange dem opp. Felles for dem alle var at de hadde levd et svært aktivt liv til de ble akutt syke. Alle kjempet for å vinne tilbake det livet de hadde hatt. Mange var blitt møtt med arrogante holdninger fra hjelpeapparatet, men det må også sies at mange leger og helsearbeidere virkelig har ønsket å forstå disse pasientene og hjelpe dem.

Etter hvert ble jeg derfor invitert til flere institusjoner for å se til pasienter og gi informasjon til personalet. Det som egentlig har forundret meg mest, er at ikke flere leger har tatt seg tid til å bli kjent med denne pasientgruppen, som ikke er beskrevet i noen lærebøker og som er for syke til å ha blitt inkludert i noen vitenskapelige studier. Verken Fluge og medarbeideres eller Larun \& Malteruds artikler $(2,3)$ omhandler disse aller sykeste pasientene med kronisk utmattelsessyndrom.
Bjerkestrand er forundret over at Larun \& Malteruds artikkel ikke har vakt oppmerksomhet. Men det kan kanskje henge sammen med at den ikke omhandler pasienter som er diagnostisert etter nye og snevrere kriterier for kronisk utmattelsessyndrom. Artikkelen deres er derfor etter min mening svært lite relevant. Hvis man bruker dagens diagnosekriterier for kronisk utmattelsessyndrom, finner man lav effekt av treningsterapi eller kognitiv atferdsterapi - tvert imot rapporteres det om skade ved slike behandlinger (4). Og, som nevnt over, de aller sykeste er ikke engang inkludert i publiserte studier.

\section{Ola Didrik Saugstad}

odsaugstad@rr-research.no

Oslo universitetssykehus, Rikshospitalet

Ola Didrik Saugstad (f. 1947) er professor i barnesykdommer ved Universitetet i Oslo, overlege i neonatologi og bestyrer ved Pediatrisk forskningsinstitutt.

Ingen oppgitte interessekonflikter.

\section{Litteratur}

1. Bjerkestrand S. Maktskiftet. Tidsskr Nor Legeforen 2012; 132: 125.

2. Larun L, Malterud K. Treningsbehandling ved kronisk utmattelsessyndrom. Tidsskr Nor Legeforen 2011; 131: 231-6.

3. Fluge $\varnothing$, Bruland $\mathrm{O}$, Risa $\mathrm{K}$ et al. Benefit from Blymphocyte depletion using the anti-CD20 antibody rituximab in chronic fatigue syndrome. A doubleblind and placebo-controlled study. PLoS One 2011; 6: e26358

4. Kindlon T. Reporting of harms associated with graded exercise therapy and cognitive behavioural therapy in myalgic encephalomyelitis/chronic fatigue syndrome. Bulletin of the IACFS/ME 2011; 19: $59-111$

Publisert først på nett 6.2. 2012.

\section{Konspirasjonsteorier og kunnskap}

I Tidsskriftet nr. 2/2011 spør Stine Bjerkestrand på lederplass hvorfor noen studier får stor medieoppmerksomhet, mens andre forbigås (1). Hun serverer konspirasjonsteorier til svar. Det handler om forskning rundt kronisk utmattelsessyndrom (ME/CFS) og hva bloggere og journalister har vært opptatt av i høst. Jeg blir i artikkelen navngitt som blogger og deltaker i en «kampanje» ledet av en (ukjent) «strateg». Dette siste medfører ikke riktighet, og hentydningene oppleves som absurde. Hva jeg har vært opptatt av gjennom de siste to år er å dele kunnskap som ikke alltid spres like godt gjennom offentlige kanaler.

En SINTEF-rapport (2) viser at pasienter med kronisk utmattelsessyndrom har vært utsatt for et helsevesen med manglende kunnskap. Jeg er tilhenger av kunnskap og setter kunnskapsdeling høyt. Som Fritt Ord-støttet blogger og lege er jeg opptatt av rask behandling til rett pasient - og blogger også om det.

Helsedirektoratet anbefaler nå nye og snevrere diagnosekriterier (3). At studien til Fluge og medarbeidere fra Haukeland universitetssykehus (4) får stor oppmerksomhet, skyldes først og fremst at dette er den første randomiserte, kontrollerte studien på et medikament mot kronisk utmattelsessyndrom noensinne og kan vise til gode resultater. Resultatene er omtalt i flere utenlandske medier. Opp mot en metaanalyse som ikke bringer nytt, er det lett å forstå hvilken som făr mest oppmerksomhet. Dette uten forkleinelse for metaanalysen eller dens forskere i seg selv. Bjerkestrand går langt $\mathrm{i}$ å insinuere at Fluge og medarbeidere fikk forskningsmidler for lett og har uttrykt at tildelingen først og fremst skyldes bloggemakt og kampanjejournalistikk. Å skulle tillegge meg evne og makt til å styre hva helseministeren bestemmer, er en sterk overdrivelse av min påvirkningskraft.

Bjerkestrands leder er tatt ut av historisk kontekst. Medienes dekning og hvordan fagfolk har sett på kronisk utmattelsessyndrom gjennom tidene er interessant. Psykosomatikerne har preget synet på pasientgruppen, med begrunnelse i forskning hvor kriteriene er så vide at psykisk syke blir inkludert.

Hvor er den norske kritiske lederartikkelen, tilsvarende den vi så i Lancet (5), der de psykosomatiske innfallsvinklene og dominansen på feltet diskuteres?

De sosiale mediene er kommet for å bli. Alle og enhver kan ytre seg og forfekte sitt syn, og man må regne med å bli korrigert. Bloggere og meningsytrere kan være høyt utdannede mennesker med kompetanse på temaene de ytrer seg om. Fremtidens helsevesen vil måtte forholde seg til brukerstemmer, pasienter og «erfarere» på en annen måte enn tidligere. De er her og de teller. Deltakerne har ennå ikke særlig mye reell makt, men de som har kunnskap, vil være med på å løfte kunnskapsrommet. Fremfor å se dette som en trussel håper jeg fremtidens leger ser brukerne av de sosiale mediene som alternative kunnskapsbaser og samhandlere som kan føre til utvikling av helsevesenet i en positiv retning. Jeg tror at det å forholde 
seg til og delta i sosiale medier blir en nødvendig og forventet del av de daglige gjøremål for helsepersonell i tiden som kommer. Å lære dette verktøyet blir pensum.

\section{Maria Gjerpe}

mariagjerpe@hotmail.com

Oslo

Maria Gjerpe (f. 1968) er lege og blogger. Arbeidssted er www.mariasmetode.no. Oppgitte interessekonflikter: Ingen, utover å blogge om helsefilosofi, sosiale medier, pasient-lege-relasjonen og kunnskap rundt kronisk utmattelsessyndrom og på den måten være en samfunnsdebattant.

\section{Litteratur}

1. Bjerkestrand S. Maktskifte. Tidsskr Nor Legeforen 2012; 132: 125

2. Lippestad JW, Kurtze N, Bjerkan AM. Status for helse- og omsorgstilbudet til pasienter med CFS/ ME i Norge. SINTEF-rapport 2011. www.sintef.no/ upload/Teknologi_samfunn/ME-rapport.pdf (30.1.2012)

3. Diagnosekriterier. www.helsedirektoratet.no/ helse-og-omsorgstjenester/cfs-me/ diagnosekriterier/Sider/default aspx (30.1.2012).

4. Fluge $\varnothing$, Bruland O, Risa K et al. 2011 Benefit from B-lymphocyte depletion using the anti-CD20 antibody rituximab in chronic fatigue syndrome. A double-blind and placebo-controlled study. PLoS One 2011; 6: e26358.

5. Frustrating survey of chronic fatigue. Lancet 1996; 348: 971. http://download.thelancet.com/pdfs/ journals/lancet/PIIS0140673605649173.pdf [30.1.2012)

Publisert først på nett 6.2. 2012.

\section{Feilaktig om mediestrategi}

I Tidsskriftet nr. 2/2012 spør Stine Bjerkestrand hvorfor noen studier får stor medieoppmerksomhet, mens andre vekker liten reaksjon (1). Dette gjør hun ved å sammenlikne responsen på en metaanalyse av tilpasset øvelsesbehandling (1) med oppmerksomheten rundt en randomisert, dobbeltblind og placebokontrollert studie av B-lymfocyttdeplesjon hos pasienter med kronisk utmattelsessyndrom (ME) (2). Responsforskjellen er påregnelig. Den første studien gjengir kjent stoff i en vidt definert pasientgruppe, mens intervensjonsstudien er den første som indikerer at en undergruppe av pasienter med kronisk utmattelsessyndrom kan få betydelig lindring av alle sykdomsrelaterte symptomer gjennom immunmanipulering (3). Den peker på at B-lymfocyttene kan spille en vesentlig rolle i symptomvedlikeholdet.

Lederskribenten har tillagt undertegnede en helt annen rolle $\mathrm{i}$ «kampanjejournalistikken» enn vi har hatt. Sent i 2009 tok den for oss ukjente Jørgen Jelstad kontakt etter å ha lest vår pilotstudie (4). Han hadde fått stipend for å skrive bok om kronisk utmattelsessyndrom, og vi var derfor åpne om vårt pågående arbeid. TV2 ble for snart tre år siden klar over studien og etterspurte analysen vår våren 2011. Utgivelsen av Jørgens Jelstads bok ble holdt tilbake for ikke å ødelegge mulighetene for å få studien publisert. Mange pasienter kjente også til våre resultater etter en kongresspresentasjon i mai 2011. Derfor var det et oppdemmet ønske om å formidle det mange opplevde som spennende resultater. Det var ingen organisert aksjon med forfatterne i spissen. TV2 valgte sin egen vinkling av nyhetssaken.

Tidsskriftlederen plasserer forfatterne i bås i synet på kronisk utmattelsessyndrom. For fire år siden var vi som onkologer uten oppfatning om sykdommens patogenese og mulige behandling. Vi resonnerte at den bedringen under cytostatikabehandling for lymfom vi så hos en pasient med mangeårig kronisk utmattelsessyndrom skyldtes B-lymfocyttreduksjon. Derfor prøvde vi etter symptomtilbakefall et monoklonalt antistoff med selektiv B-lymfocyttdeplesjon som virkning. Hun og to påfølgende pasienter oppnådde betydelig symptombedring (4). Deretter fulgte den publiserte studien og års hardt laboratoriearbeid for å eksplorere mekanismer bak det vi så. Vi har aldri uttalt oss om andre behandlingsformer (selv om vi leser fiktive intervjuer med oss om det).

Flere hundre mottatte sykehistorier fra pasienter som ønsker å delta i kliniske studier viser at dagens etablerte behandling etterlater en stor gruppe mennesker med elendig livskvalitet og små håp om bedring. Kanskje Tidsskriftet burde uttrykke glede over et nytt behandlingskonsept som kan gi innsikt $i$ sykdomsmekanismene $o g$ håp til dem som over år lever med patologisk utmattelse, smerter og kognitive symptomer, og der de hardest rammede er $i$ en nærmest vegetativ tilværelse?

\section{Olav Mella}

olav.mella@helse-bergen.no

Haukeland universitetssykehus

Universitetet i Bergen

Øystein Fluge

Haukeland universitetssykehus

Forfatterne er ansatt i Helse Bergen, som gjennom Bergen Teknologioverføring har søkt patent på konseptet B-lymfocyttdeplesjon ved kronisk utmattelsessyndrom (ME). Institusjonen kan få inntekter i fremtiden dersom medikamenter blir bekreftet som virksomme ved sykdommen. Olav Mella og Øystein Fluge er benevnt som oppfinnere i patentsøknaden.

Olav Mella (f. 1951) er avdelingsoverlege ved Kreftavdelingen, Haukeland universitetssykehus, og professor II ved Seksjon for onkologi, Institutt for indremedisin, Universitetet iBergen.

Ingen oppgitte interessekonflikter.
Øystein Fluge (f. 1961) er overlege og forsker ved Kreftavdelingen, Haukeland universitetssykehus.

Oppgitte interessekonflikter: Forfatteren har mottatt støtte til kongressreiser fra Roche og fra Helse-Bergen.

\section{Litteratur}

Bjerkestrand S. Maktskiftet.Tidsskr Nor Legeforen 2011; 132: 125

2. Larun L, Malterud K. Treningsbehandling ved kronisk utmattelsessyndrom. Tidsskr Nor Legeforen 2011; 131: 231-6.

3. Fluge $\emptyset$, Bruland $\mathrm{O}$, Risa $\mathrm{K}$ et al. Benefit from Blymphocyte depletion using the anti-CD20 antibody rituximab in chronic fatigue syndrome. A doubleblind and placebo-controlled study. PLOS ONE 2011: 6: e26358.

4. Fluge $\varnothing$, Mella 0 . Clinical impact of B-cell depletion with the anti-CD20 antibody rituximab in chro nic fatigue syndrome: a preliminary case series. BMC Neurology 2009; 9: 28 .

Publisert først på nett 6.2. 2012

\section{Uriktig om TV 2s journalistikk}

I Tidsskriftet nr. 2/2012 retter Stine Bjerkestrand en rekke grove beskyldninger mot TV 2s dekning av Øystein Fluge og Olav Mellas forskning på kronisk utmattelsessyndrom (ME) (1). De to Haukeland-legenes studie om rituximabs positive effekt på pasientene ble bredt omtalt på TV 2 .

Bjerkestrand mener at vi i TV 2 blant annet har vært ensidige, at vi systematisk har overtolket resultatene og unnlatt å stille kritiske spørsmål. Hun fremstiller oss som nyttige idioter for organiserte grupper som presser frem millionbevilgninger til forskerne.

Undertegnede er en av journalistene som har jobbet med denne saken for TV 2. Jeg mener kritikken er uriktig.

Bjerkestrand sammenlikner rituximabstudien med en metastudie der effekten av trening for pasienter med kronisk utmattelsessyndrom analyseres. Hvorfor fikk bare den ene studien oppmerksomhet?

Metastudien viser at trening kan ha en viss positiv effekt for noen pasienter. Det er lite nytt i dette: Cochrane-instituttet publiserte en liknende studie i 2004 (2). I tillegg er dokumentasjonsstyrken bare moderat til svak, og studien sier ingenting om årsakssammenhenger. Gradert trening fremstår mer som symptomlindring enn som en målrettet behandling pasientene kan bli friske av.

Rituximabstudien har på sin side ifølge forfatterne potensial til å revolusjonere behandlingen for millioner av pasienter. Selve behandlingsmetoden, deplesjon av B-cellene i immunforsvaret, gir også en indikasjon om sykdommens virkemåte. Selvsagt må studien repliseres, men kontrasten til det svært mange norske leger 